\title{
Structural trends and basement rock subdivisions in the western Gulf of St. Lawrence: Discussion
}

\author{
Clinton J. St. Peter and Leslie R. Fyffe \\ New Brunswick Department of Natural Resources and Energy, Minerals and Energy Division, \\ P.O. Box 6000, Fredericton, New Brunswick E3B 5H1, Canada
}

Date Received July 13, 1990

Date Accepted September 10, 1990

\begin{abstract}
Durling and Marillier (1990) have been able to trace Appalachian structural trends from mainland New Brunswick and Gaspé, Québec to the offshore Gulf of St. Lawrence based mainly on marine seismic data. We would like to comment on their structural correlations in southeastern New Brunswick and Prince Edward Island (Fig. 1) and present an alternate interpretation that we believe is more in accord with stratigraphic, structural, and geophysical evidence.

We agree with Webb (1969) and van de Poll (1983) that the Egmont Bay basement high of Prince Edward Island (P. E. I.) is the continuation of the Indian Mountain horst exposed in the inlier north of Moncton (at G on Fig. 1) in New Brunswick (Gussow, 1953). This correlation is supported by the following: (1) the southeastern side of the Egmont Bay high is characterized by very thick Horton Group clastic rocks and Windsor Group evaporites that are evident in P.E.I. by intersections in Imperial MacDougall and Wellington holes (Webb, 1969), and similarly in New Brunswick by a half-graben of thick Windsor Group evaporites just east of Sussex at Plumweseep and Penobsquis (see Gussow, 1953, sections E-Fand G-H; and Howie, 1988, figs. 19,28 , and 31); (2) the southeastern side of the horst is defined by a post-Windsor Group reverse fault (see Durling and Marillier, 1990, fig. 8, section E-F), which in New Brunswick has been called the Petitcodiac-Berry Mills Fault or the KennebecasisBerry Mills Fault (Gussow, 1953; Webb, 1963, 1969; St. Peter, 1989); (3) the Indian Mountain horst in New Brunswick has been interpreted from stratigraphic and structural evidence as a transpressive positive flower structure (see Webb, 1963, figs. 9, 12 , section $A-A^{\prime}$ ), in agreement with the seismic interpretation of Durling and Marillier (1990) as shown on their figure 8, section E-F. From the foregoing, we would contend that the Indian Mountain horst and Egmont Bay high are a continuous positive transpressive structure bounded on the southeast by the Kennebecasis-Berry Mills Fault and on the northwest by the Smith Creek Fault. Volcanic and intrusive rocks of probable Precambrian age exposed in the Jordan Mountain inlier (Fon Fig. 1) and on the Kingston Peninsula, together with those at Indian Mountain, appear to form separate slices of a northeasterly trending strike-slip duplex.

The continuous northeasterly trend of the Precambrian rocks beneath Carboniferous strata is identifiable from both gravity
\end{abstract}

and magnetic trends (Geological Survey of Canada, 1988). We would, therefore, not curve the Belleisle Fault to the east across the trend of the Smith Creek and Kennebecasis-Berry Mills faults as required by the interpretation of Durling and Marillier. Instead, we would maintain a northeasterly strike and, thereby, place the Belleisle Fault on the northern margin of the Horton half-graben in the Cascumpec Basin, analogous to its position north of the Indian Mountain horst in New Brunswick (W. Nickerson, personal communication, 1990). The presence of graphitic slates at a depth of $616 \mathrm{~m}$ in a borehole at Buctouche (McMullen, 1920), which are similar to the Ordovician rocks in the Thomes Brook inlier (E on Fig. 1), is consistent with this northeasterly structural trend.

Durling and Marillier (1990) claimed that the northern margin of the pre-Horton Cascumpec basin is bounded by the extension of the Fredericton Fault (see also McCutcheon and Robinson, 1987 and Thomas and Willis, 1989). However, magnetic contours continue to the northeast, well offshore of P.E.I. (Geological Survey of Canada, 1988), suggesting that the Fredericton Fault does not swing to the east-northeast as indicated on figures 1 and 5 of Durling and Marillier (1990). It should also be noted that the placement of a crustal boundary along a curved Fredericton Fault by Thomas and Willis (1989) on the basis of magnetic data did not consider the effect of a granitic pluton intersected in boreholes at Canaan Station and Coal Branch (Fig. 1). Fresh biotites and homblendes in the chip samples readily distinguish this probable Devonian granite from chloritized granite of Precambrian aspect intersected in boreholes southeast of Moncton. The western part of the pluton is exposed in the inlier at Thornes Brook where the presence of alkali feldspar megacrysts up to $6 \mathrm{~cm}$ in length attests to its slow cooling and large areal extent.

The Fredericton Fault in New Brunswick (Fig. 1) is internal to Silurian clastic turbidites of the Fredericton Trough (Fyffe, 1990). These Silurian rocks are known to extend as far east as the Coal Creek inlier (A on Fig. 1) and are likely represented offshore by the pre-Horton strata of the North Point Basin. As the Basswood Ridge-Pendar Brook Fault separates Silurian from Ordovician rocks on the mainland (Fyffe, 1990), we correlate it with the fault through the northwestern tip of P.E.I. 


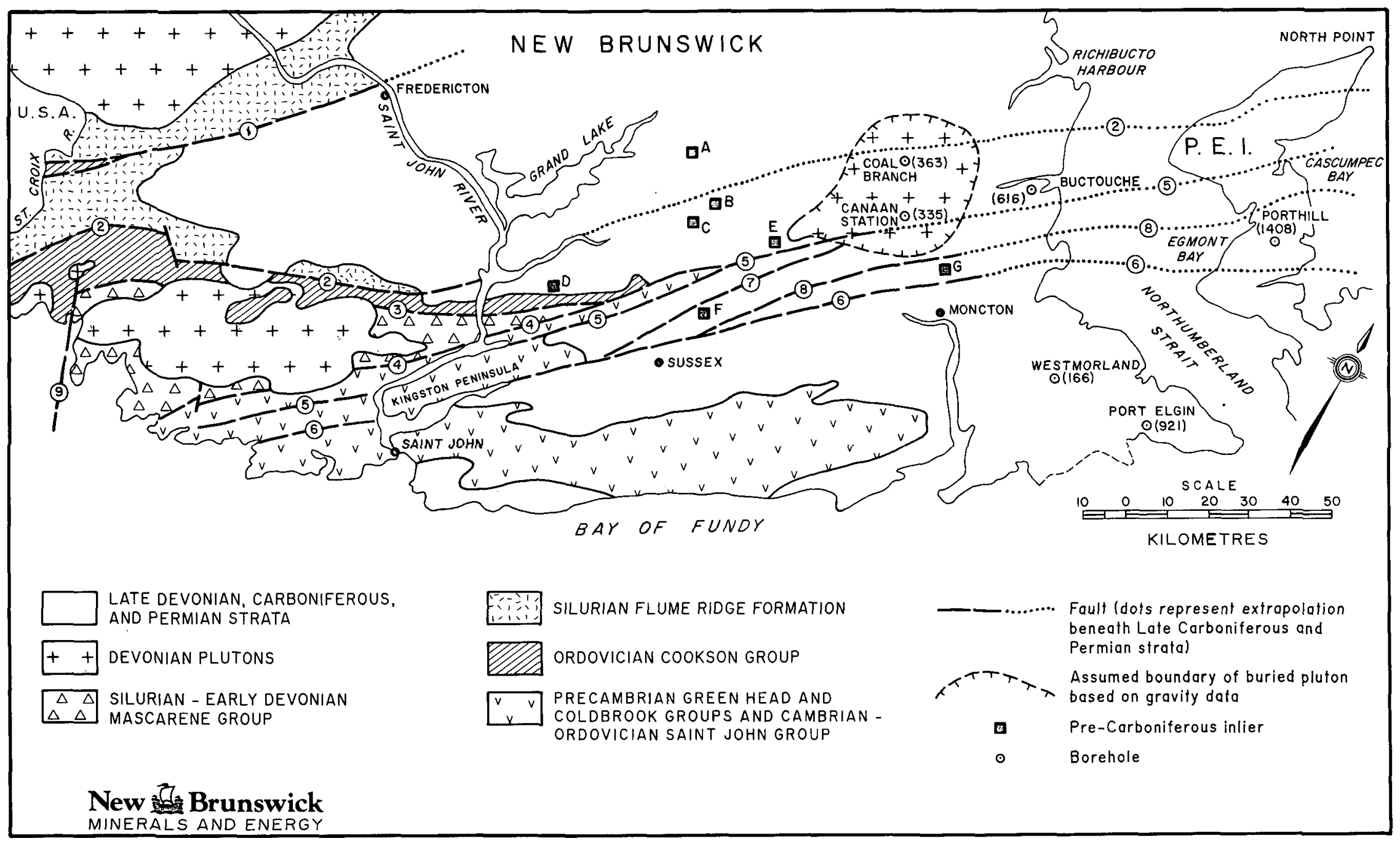

Fig. 1. Geology map of southern New Brunswick and northem Prince Edward Island.

Faults: 1 - Fredericton; 2 - Basswood Ridge-Pendar Brook; 3 - Falls Brook-Taylor Brook; 4 - Wheaton Brook; 5 - Belleisle; 6 - Kennebecasis-Berry Mills; 7 - Jordan Mountain; 8 - Smith Creek; 9 - Oak Bay.

Inliers: A - Coal Creek; B - Forks Stream; C - Canaan River; D - Henderson Brook; E - Thomes Brook; F - Jordan Mountain; G - Indian Mountain

Boreholes are denoted by their geographic location. Numbers in brackets give depth to basement in metres. 
The presence of a strike-slip duplex along the northern margin of the Avalon Terrane in New Brunswick creates a more complicated boundary relationship with the Gander Terrane in comparison to that in Newfoundland. The boundary has variously been placed at the Belleisle Fault (Brown and Helmstaedt, 1970), Wheaton Brook Fault (McCutcheon, 1981), Falls BrookTaylor Brook Fault (Fyffe and McLeod, 1990; McLeod et al., 1990), and the Fredericton Fault (Williams, 1979). Further detailed isotopic studies such as those of Whalen et al. (1989) should help define the elusive Avalon/Gander boundary on the mainland.

BROWN, R.L. and HELMSTAEDT, H. 1970. Deformation history in part of the Lubec-Belleisle zone of southem New Brunswick. Canadian Journal of Earth Sciences, 7, pp. 748-767.

DURLING, P.W. and MARILLIER, F.J.Y. 1990. Structural trends and basement rock subdivisions in the western Gulf of St. Lawrence, northern Appalachians. Atlantic Geology, 26, pp. 79-95.

FYFFE, L.R. 1990. Bedrock geology of the Moores Mills area, Charlotte County, New Brunswick. In Project Summaries for 1989, Fourteenth Annual Review of Activities. Edited by S.A. Abbott. New Brunswick Department of Natural Resources and Energy, Minerals and Energy Division, Information Circular 89-2 (second edition), pp. 40-51.

FYFFE, L.R. and McLEOD, M.J. 1990. Terrane boundaries in southwestern New Brunswick. Geological Society of America, Annual Meeting Northeastern Section, Abstracts With Programs, 22, No. 2, p. A19.

GEOLOGICAL SURVEY OF CANADA. 1988. Magnetic anomaly maps of the Continuated Margin of Eastem Canada. Map 1709A, scale 1:5000 000 .

GUSSOW, W.C. 1953. Carboniferous stratigraphy and structural geology of New Brunswick, Canada. American Association of Petroleum Geologists, Bulletin 37, pp. 1713-1816.

HOWIE, R.D. 1988. Upper Paleozoic evaporites of southeastern Canada. Geological Survey of Canada, Bulletin 380, 120 p.

McCUTCHEON, S.R. 1981. Revised stratigraphy of the Long Reach area, southem New Brunswick: Evidence for major, northwestward-directed Acadian thrusting. Canadian Journal of Earth Sci- ences, 18, pp. 646-656.

McCUTCHEON, S.R. and ROBINSON, P.T. 1987. Geological constraints on the genesis of the Maritimes Basin, Atlantic Canada. In Sedimentary Basins and Basin-forming Mechanisms. Edited by C. Beaumont and A.J. Tankard. Canadian Society of Petroleum Geology, Memoir 12, pp. 287-297.

McLEOD, M.J., JOHNSON, S.C., and RUTTENBERG, A.A. 1990. Compilation and correlation of southern New Brunswick geology, Charlotte, Queens, and Kings counties. In Project summaries for 1989, Fourteenth Annual Review of Activities. Edited by S.A. Abbott. New Brunswick Department of Natural Resources and Energy, Minerals and Energy Division, Information Circular 89-2 (second edition), pp. 151-159.

McMULLEN, W.E. 1920. Mining report for 1919. In 59th Annual Report. Department of Lands and Mines, New Brunswick, pp. 4272.

ST. PETER, C.J. 1989. Horton Group lithofacies and generalized geology of the eastern part of the Moncton Subbasin. New Brunswick Department of Natural Resources and Energy, Minerals and Energy Division, Map Plate 89-102.

THOMAS, M.D. and WILLIS, C. 1989. Gravity modelling of the Saint George Batholith and adjacent terrane within the Appalachian Orogen, southern New Brunswick. Canadian Journal of Earth Sciences, 26, pp. 561-576.

VAN DE POLL, H.W. 1983. Geology of Prince Edward Island. Department of Energy and Forestry, Energy and Minerals Branch, Province of Prince Edward Island, Report 83-1, 66 p.

WEBB, G.W. 1963. Occurrence and exploration significance of strikeslip faults in southern New Brunswick, Canada. American Association of Petroleum Geologists, Bulletin, 47, pp. 1904-1927.

WEBB, G.W. 1969. Paleozoic wrench faults in Canadian Appalachians. In North Atlantic Geology and Continental Drift. Edited by Marshall Kay. American Association of Petroleum Geologists, Memoir 12 , pp. 754-788.

WHALEN, J.B., HAGNER, E., and JENNER, G.A. 1989. Nature of Canadian Appalachian basement terranes as inferred from a Nd isotopic transect. Geological Society of America, Annual Meeting Southeastern Section, Abstracts With Programs, 21, p. A201.

WILLIAMS, H. 1979. Appalachian Orogen in Canada. Canadian Journal of Earth Sciences, 16, pp. 792-807. 